\title{
Pengujian Karakteristik Campuran HRS-Base Menggunakan LGA Sebagai Pengganti Aspal Minyak
}

\author{
Dodo P. Randelabi *1, Rais Rachman *2, Alpius *3 \\ *1 Mahasiswa Program Studi Teknik Sipil, Universitas Kristen Indonesia Paulus, Makassar, Indonesia \\ dodoprawiror@gmail.com \\ *2,3 Dosen Program Studi Teknik Sipil, Universitas Kristen Indonesia Paulus, Makassar, Indonesia \\ rais.rachman@gmail.com \& alpiusnini@gmail.com,
}

\begin{abstract}
ABSTRAK
Penelitian ini bertujuan untuk menganalisis nilai stabilitas, VIM, VFB, MQ dengan subtitusi kadar LGA 0\% 2,5\%,5\%, 7,5\%, 10\%, $12,5 \%$ dan $15 \%$ terhadap Aspal keras dengan kadar aspal $5 \%$.

Metodologi dalam penelitian ini adalah melakukan serangkaian pengujian karakteristik berupa agregat kasar, agregat halus, filler dan aspal lalu merancang komposisi campuran kemudian membuat benda uji berupa campuran HRS (HRS Base) Kasar serta pengujian Marshall untuk mendapatkan Indeks Perendaman (IP) / Indeks Kekuatan sisa (IKS) / Durabilitas campuran dengan menggunakan kadar aspal optimum

Hasil penelitian yang dilakukan di laboratorium Jalan dan Aspal Fakultas Teknik Jurusan Sipil Universitas Kristen Indonesia Paulus Makassar, menunjukkan penggantian aspal minyak dengan beberapa varian LGA 0\%, 2,5\%, 5\%, 7,5\%, 10\%, 12,5\%, 15\% memperoleh nilai Stabilitas, VIM, VFB, VMA, dan MQ. Hasilnya menunjukkan bahwa kadar aspal optimum yaitu $10 \%$ dengan nilai Stabilitas $3083,60 \mathrm{Kg}$, nilai VIM 0,19\%, VMA 18,602 \%, VFB 67,974, MQ 906,88 Kg/mm, dan indeks perendaman (IP) $95,21 \%$.
\end{abstract}

Kata kunci : Karakteristik, HRS Base, LGA, Marshall

\section{ABSTRACT}

This study aims to analyze the value of stability, VIM, VFB, MQ with substitution LGA content $0 \% 2.5 \%, 5 \%, 7.5 \%, 10 \%, 12.5 \%$ and $15 \%$ against hard asphalt with asphalt content of $5 \% .$.

The methodology in this research is to conduct a series of testing of characteristics in the form of coarse aggregates, fine aggregates, fillers and asphalt and then design the composition of the mixture then make the specimen in the form of a rough HRS (HRS Base) and Marshall testing to obtain an Immersion Index (IP) / Residual Strength Index ( IKS) / Durability of the mixture using optimum asphalt content

The results of research conducted at the Road and Asphalt Laboratory of the Faculty of Civil Engineering, Indonesian Christian University Paulus Makassar, showed the replacement of oil asphalt with several variants of LGA $0 \%, 2.5 \%, 5 \%, 7.5 \%, 10 \%, 12.5 \%$ , $15 \%$ obtained the value of Stability, VIM, VFB, VMA, and MQ. The results showed that the optimum asphalt content was $10 \%$ with a Stability value of $3083.60 \mathrm{~kg}$, VIM value of $0.19 \%$, VMA of $18,602 \%$, VFB of $67,974, \mathrm{MQ}$ of $906.88 \mathrm{~kg} / \mathrm{mm}$, and immersion index (IP) of $95.21 \%$.

\section{Keywords: Characteristics, HRS Base, LGA, Marshall}

\section{PENDAHULUAN}

Aspal Buton (LGA) merupakan aspal alam yang berada di Indonesia, yaitu di Pulau Buton, Sulawesi Tenggara. Asbuton atau Aspal batu Buton ini pada umumnya berbentuk padat yang terbentuk secara alami akibat proses geologi. Proses terbentuknya asbuton berasal dari minyak bumi yang terdorong muncul ke permukaan menyusup di antara batuan yang porous.

Penggunaan aspal minyak untuk pekerjaan pengaspalan jalan sebagian besar menggunakan aspal impor, sementara ketersedian aspal minyak semakin terbatas dan harga yang cenderung naik terus seiring dengan harga pasar minyakmentah dunia. Untuk menjawab kendala di atas, maka salah satu alternatif yangmenjanjikan adalah penggunaan aspal Buton yaitu Asbuton sebagai bahansubsitusi aspal minyak. Pada saat ini teknologi Asbuton telah berkembang pesatmeliputi Asbuton butir, Asbuton pra-campur dan Asbuton semi ekstrasksi maupun Asbuton ekstraksi.Kadar bitumen dalam Asbuton sangat bervariasi dari $10 \%$ sampai $40 \%$. Pada beberapa lokasi ada pula Asbuton dengan kadar bitumen sampai dengan nilai 90\%. Bitumen Asbuton memiliki kekerasan yang sangat bervariasi.

Lapisan lentur biasanya memakai Aspal sebagai bahan untuk merekatkan, pada pengujian ini peneliti mencoba untuk mensubtitusi aspal minyak dengan menggunakan LGA, selain jumlahnya yang tersedia cukup banyak di Indonesia LGA juga merupakan material yang memiliki potensial yang begitu besar. LGA sangat cocok untuk konstruksi berat terutama di daerah tropis seperti Indonesia selain daripada itu LGA juga tidak mengandung parafin dan sedikit kadar 
sulfur sehigga kualitasnya lebih tinggi. yang baik dalam berikut penjelasan mengenai LGA [1]. LGA merupakan aspal alam yang berada di Indonesia, yaitu di Pulau Buton, Sulawesi Tenggara. LGA pada umumnya berbentuk padat yang terbentuk secara alami akibat proses geologi. Proses terbentuknya LGA berasal dari minyak bumi yang terdorong muncul kepermukaan .

HRS (HRS) adalah lapisan penutup yang terdiri dari campuran agregat bergradasi senjang, filler dan aspal keras dengan perbandingan tertentu yang dicampur dan dipadatkan secara panas (dalam suhu tertentu, minimum $124^{\circ} \mathrm{C}$ ), dengan ketebalan padat $2,5 \mathrm{~cm}$ atau $3 \mathrm{~cm}$. Konstruksi perkerasan HRS dalam penggunaanya dibagi menjadi dua kelas yaitu kelas $A$ dan kelas B [2]. Perbedaan kedua konstruksi perkerasan tersebut terdapat pada gradasi agregat yang digunakan, beban lalu lintas dan segi pemakaian. Penggunaan campuran lapisan tipis aspal beton biasa tujuannya untuk memberikan dukungan pada lapisan yang ada dibagian bawahnya selain itu lapisan HRS ini fungsinya sebagai lapisan yang tahan atau kedap terhadap air. Lapisan tipis aspal beton atau HRS ini memiliki sifat yang yaitu rongga dalam campuran cukup besar yang mengakibatkan dapat menyerap aspal dalam jumlah yang banyak dan tanpa terjadi bleeding [3]. Lapisan ini juga cukup mudah dalam proses pemadatan sehingga lapisan yang dihasilkan mempunyai kekedapan terhadap air dan udara tinggi.

Karakteristik marshall campuran beraspal sebagai berikut [4] :

1. Stabilitas adalah kemampuan lapisan perkerasan menerima beban lalu-lintas tanpa mengalami perubahan bentuk tetap (deformasi permanen) seperti gelombang, alur (rutting), maupun mengalami bleeding.

2. Kelelehan (flow) adalah deformasi vertical yang terjadi mulai awal pembebanan sampai kodisi stabilitas menurun, yang menunjukkann besarnya deformasi yang terjadi pada lapisan perkerasan akibat menahan beban yang diterimanya.

3. Voids in Mixture (VIM) Rongga di dalam Campuran (VIM) dalam campuran perkerasan jalan terdiri atas ruangan udara diantara agregat yang terselimuti aspal.

4. Void in Mineral Aggregate (VMA) adalah ruang diantara partikel agregat pada suatu perkerasan beraspal, termasuk rongga udara dan volume aspal efektif (tidak termasuk volume aspal yang diserap agregat).

5. VFB (Rongga terisi aspal) adalah persen rongga yang terdapat diantara partikel agregat yang terisi oleh aspal (tidak termasuk aspal yang diserap oleh agregat).

6. Marshall Quotient, nilai $M Q$ menyatakan sifat kekuatan suatu campuran. Bila nilai $\mathrm{MQ}$ terlalu tinggi, maka campuran akan cenderung terlalu kaku dan mudah retak. Sebaliknya bila nilai $\mathrm{MQ}$ terlalu rendah, maka perkerasan menjadi lentur dan cenderung kurang stabil.

7. Indeks Kekuatan Sisa adalah perbandingan antara stabilitas benda uji selama perendaman dan stabilitas benda uji standar dinyatakan dalam persen. IKS digunakan untuk menentukan kepekaan kekuatan beton aspal yang dinyatakan dengan nilai stabilitas akibat penurunan kekuatan benda uji akibat kerusakan oleh air.

Beberapa peneliti sebelumnya yang meneliti LGA untuk perkerasan jalan antara lain

Rachman $\mathrm{R}$ [5] meneliti kinerja filler asbuton dalam campuran mortar hot rol asphalt (HRA). Dari hasil penelitian didapatkan stabilitas campuran Mortar HRA dengan filler semen lebih besar dibandingkan dengan campuran Mortar HRA dengan filler asbuton. Hal ini disebabkan karena faktor berkurangnya filler asbuton yang berubah menjadi bitumen, sehingga kekakuan campuran Mortar HRA dengan filler asbuton menjadi menurun. Nilai kelelehan campuran Mortar HRA yang menggunakan filler asbuton lebih besar bila dibandingkan dengan campuran Mortar HRA yang menggunakan filler semen. Sedangkan nilai kadar aspal optimum campuran Mortar HRA yang menggunakan filler asbuton lebih kecil bila dibandingkan dengan campuran Mortar HRA yang menggunakan filler semen. Hal ini disebabkan adanya kontribusi bitumen dari asbuton pada jumlah total kadar bitumen campuran. Cukup jauhnya perbedaan nilai Marshall Quotient Mortar HRA dengan filler asbuton dengan nilai Marshall Quotient minimum disebabkan karena cukup tingginya nilai kelelehan yang tidak diimbangi oleh nilai stabilitas yang besar. Sedangkan dari sisi durabilitas, campuran Mortar HRA yang menggunakan filler asbuton memiliki tingkat durabilitas lebih tinggi bila dibandingkan dengan durabilitas campuran Mortar HRA yang menggunakan filler semen.

Rachman R, Alpius [6] meneliti kinerja campuran hra akibat pengaruh modifier pada filler asbuton mikro hasil penelitian menunjukkan campuran HRA yang menggunakan modifier akan membutuhkan aspal minyak paling sedikit, hal ini ditunjukkan oleh kadar aspal optimumnya, kemudian juga mempunyai kinerja lebih baik juga, hal ini ditunjukkan oleh nilai Marshall Quotient-nya. Dan dari kedua jenis modifier yang digunakan, campuran yang menggunakan asbutonmodifier menunjukkan indikasi secara umum lebih baik dibandingkan campuran yang menggunakan modifier minyak tanah.

Selain itu beberapa peneliti yang meneliti campuran HRS antara lain :

Yudi et al [7] meneliti Karakteristik Campuran AC-WC dan AC-BC Menggunakan Bahan Tambah Serat ljuk . Putra at.al [8], meneliti Pengaruh Penggunaan Serat Rotan Terhadap Stabilitas Dan Durabilitas Untuk Bahan Tambah Campuran Lataston. Kamba C, 
Rachman R [9], meneliti Marshall Characteristics Test On Hot Rolled Sheet Base Combine Using Nickel Slag For Half Gap Graded. Kusuma A, Rachman R [10], meneliti Characteristics of Nickel Slag For Gradient Gap on Mixtured Hot Rolled Sheet Base.

Tujuan penelitian ini adalah menganalisis nilai stabilitas, VIM, VFB, MQ dengan subtitusi kadar LGA $0 \% 2,5 \%, 5 \%, 7,5 \%, 10 \%, 12,5 \%$ dan $15 \%$ terhadap Aspal keras dengan kadar aspal $5 \%$.

\section{METODE PENELITIAN}

Dalam melaksanakan sebuah penelitian pertama yang di siapkan ialah material yang akan kita teliti di laboratorium. Material yang akan diteliti saat ini merupakan agregat yang berasal dari bili-bili Kabupaten Gowa Sulawesi selatan dengan aspal alam yang berasal dari Buton dimana material dibawah ke Makassar dan di telitidi laboratorium UKI Paulus Makassar.

Standar digunakan mengacu pada spesifikasi umum Bina Marga Tahun 2018 Divisi 6 dan Spesifikasi Khusus Interim Campuran Beraspal Panas dengan LGA Lawele (SKh-6.6.3.1,Tahun 2016. Hasil karakteristik material, dibandingkan dengan besaran nilai pada spesifikasi yang digunakan. Jika memenuhi Spesifikasi maka dilanjutkan ke rancangan campuran, dan jika tidak memenuhi spesifikasi maka langsung ke analisis dan pembahasan.

\section{Pemeriksaan Karakteristik Agregat}

Analisa saringan menggunakan mengacu pada SNI 03-1968-1990, Berat Jenis Curah dan Penyerapan Air Agregat Kasar (SNI 1969-2008) dan Agregat Halus (SNI 1970-2008), Pengujian Abrasi dengan Mesin Los Angeles (mengacu pada SNI 2417;2008), Pengujian kadar lumpur / sand equivalent test ( mengacu pada SNI ASTM C117:2012), Kelekatan Agregat Terhadap Aspal ( mengacu pada SNI 2439;2011), Material Lolos Saringan No.200 (mengacu pada SNI ASTM C1172012), Partikel Pipih dan Lonjong (mengacu pada ASTM D4791-10), Pengujian Berat Jenis Filler (mengacu pada SNI C136:2012)

\section{Pengujian Karakteristik Aspal}

Metode yang digunakan dalam penelitian ini adalah sebagai berikut Pengujian Penetrasi pada $25^{\circ} \mathrm{C}(0,1$ $\mathrm{mm}$ ) (mengacu pada SNI 2456:2011), Pengujian Titik Lembek $\left({ }^{\circ} \mathrm{C}\right)$ (mengacu pada SNI 2434-2011), pengujian Daktilitas $\left(25^{\circ} \mathrm{C}\right.$ ) (mengacu SNI 2432;2011). Pengujian Titik Nyala $\left({ }^{\circ} \mathrm{C}\right)$ mengacu pada SNI 2433;2011, Berat Jenis mengacu pada SNI $2441 ; 2011$, Berat Yang Hilang (TFOT) mengacu pada SNI-06-2441-1991, Pengujian penetrasi pada TFOT (\%) mengacu pada SNI 2456:2011.

\section{Pengujian Campuran Terhadap Uji Marshall}

Pengujian ini untuk mendapatkan nilai Stabilitas, Kelelehan (Flow) Marshall Quotion (MQ), rongga terisi aspal (VFB), rongga dalam campuran (VIM) dan rongga dalam agregat (VMA).

\section{Pengujian Campuran Terhadap Uji Marshall immertion}

Pengujian ini untuk dipilih aspal denan nilai yang tertinggi dilihat dari Kadar aspal Optimum dan campuran yang dihasilkan kemudian direndam selama 24 jam untuk medapatkan Indeks Kekuatan sisa atau indeks perendaman.

\section{Pembuatan Benda Uji}

Jumlah benda uji seperti pada tabel 1 .

Tabel 1. Komposisi campuran dengan kadar aspal 5\%

\begin{tabular}{ccccc}
\hline No. & $\begin{array}{c}\text { Kadar } \\
\text { subtitusi LGA } \\
\text { butir }\end{array}$ & $\begin{array}{c}\text { Berat LGA } \\
\text { tiap varian } \\
(\mathrm{gr})\end{array}$ & $\begin{array}{c}\text { Marshall } \\
\text { Konvensional }\end{array}$ & $\begin{array}{c}\text { Marshall } \\
\text { Immertion }\end{array}$ \\
\hline 1 & $0 \%$ & 0 & 3 & 3 \\
\hline 2 & $2,50 \%$ & 1,65 & 3 & 3 \\
\hline 3 & $5 \%$ & 3,3 & 3 & 3 \\
\hline 4 & $7,50 \%$ & 4,95 & 3 & 3 \\
\hline 5 & $10 \%$ & 6,6 & 3 & 3 \\
\hline 6 & $12,50 \%$ & 8,25 & 3 & 3 \\
\hline 7 & 15 & 9,9 & 3 & 3 \\
\hline & TOTAL & & 21 & 21 \\
\hline
\end{tabular}

\section{HASIL DAN PEMBAHASAN}

\section{Hasil Pengujian}

\section{a. Karakteristik Agregat}

Hasil pengujian keausan agregat dengan Los Angeles diperoleh nilai ketahanan agregat kasar terhadap keausan dari Fraksi A adalah 4,96\%, Fraksi B adalah 4,48 \%, Fraksi C adalah 4,20\% dan Fraksi D adalah $3,92 \%$. Spesifikasi Umum Bina Marga 2018 yaitu dengan nilai maksimum $40 \%$.

Pengujian berat jenis dan penyerapan agregat kasar yang menggunakan dua sampel diperoleh nilai untuk Berat Jenis Bulk adalah 2,64, berat jenis SSD adalah 2,69, berat jenis semu adalah 2,77 dan Penyerapan Air adalah 1,86\%. Persyaratan Spesifikasi Umum Bina Marga 2018 yaitu untuk Berat Jenis Bulk, Berat Jenis SSD dan Berat Jenis Semu adalah minimal 2,5 dan Penyerapan Air maksimal 3\%

Pengujian Berat Jenis dan Penyerapan Agregat Halus diperoleh nilai untuk Berat Jenis Bulk adalah 2,56, Berat Jenis SSD adalah 2,60, Berat Jenis Semu adalah 2,66 dan Penyerapan Air adalah 1,52 \%. Persyaratan sesuai Spesifikasi Umum Bina Marga 2018 untuk Berat Jenis Bulk, Berat Jenis, Berat Jenis Semu adalah minimal 2,5 dan Penyerapan Air maksimal adalah $3 \%$.

Gambar 1 adalah grafik dari hasil pengujian analisa saringan dimana dari gambar tersebut grafik gradasi 
agrgat campuran berada antara batas atas dan batas bawah dari spesifikasi Umum Bina Marga 2018.

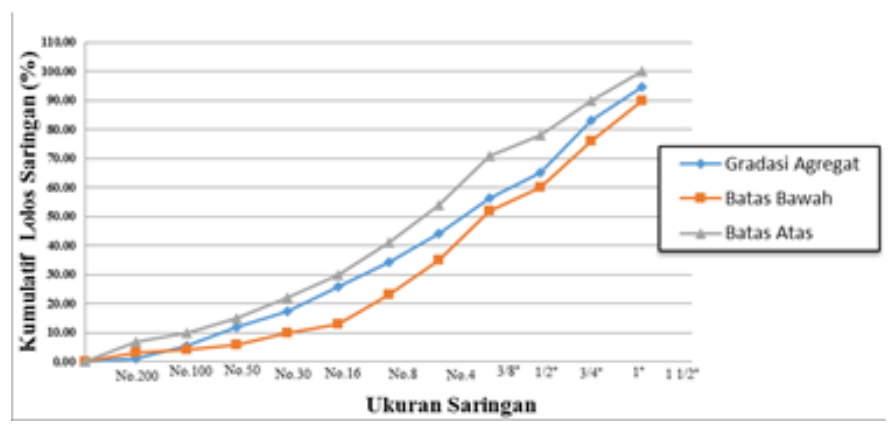

Gambar 1. Grafik Analisa Saringan Agregat Kasar dan Halus

Hasil pengujian material lolos saringan No. 200 diperoleh nilai 8,0 \%, persyaratan yang ditetapkan pada Spesifikasi Umum Bina Marga 2018 yaitu maksimal $10 \%$.
Hasil pengujian nilai setara lumpur yang menggunakan 2 (dua) sampel adalah nilai Sand Equivalen (SE) adalah 95,16\% dan kadar lumpur 4,84 $\%$. Persyaratan Spesifikasi Umum Bina Marga 2018 yaitu minimal 50\% untuk Sand Equivalen dan maksimal 5\% untuk kadar lumpur.

Hasil Pengujian Partikel Kepipihan dan Kelonjongan Agregat Kasar diperoleh partikel pipih yaitu 11,37\%, $21,81 \%, 9,01 \%$. Dan partikel lonjong yaitu $9,76 \%$, $30,61 \%, 8,22 \%$. Persyaratan adalah maksimal $10 \%$.

\section{b. Karakteristik Aspal}

Aspal yang digunakan dalam penelitian ini untuk pembuatan campuran HRS Base adalah aspal minyak penetrasi 60/70 dimana hasil pengujian karakteristik aspal dapat dilihat pada Tabel 2.minyak penetrasi 60/70 dimana hasil pengujian karakteristik aspal dapat dilihat pada Tabel 2.

Tabel 2. Hasil pengujian Karakteristik Aspal

\begin{tabular}{|c|c|c|c|c|c|c|}
\hline \multirow{2}{*}{ Jenis Pengujian } & \multirow{2}{*}{ Metode } & \multirow{2}{*}{ Hasil } & \multicolumn{2}{|c|}{ Spesifikasi Bina Marga } & \multirow{2}{*}{ Satuan } & \multirow{2}{*}{ Ket } \\
\hline & & & Min & Maks & & \\
\hline Penetrasi pada $25^{\circ} \mathrm{C}$ & SNI 2456-2011 & 67 & 60 & 79 & $0,1 \mathrm{~mm}$ & $\begin{array}{l}\text { Memenuhi } \\
\text { Standar }\end{array}$ \\
\hline Daktilitas & SNI 2432-2011 & 150 & 100 & - & $\mathrm{Cm}$ & $\begin{array}{l}\text { Memenuhi } \\
\text { Standar }\end{array}$ \\
\hline Titik Lembek $\left({ }^{\circ} \mathrm{C}\right)$ & SNI 2434-2011 & 51,7 & 48 & 58 & ${ }^{\circ} \mathrm{C}$ & $\begin{array}{l}\text { Memenuhi } \\
\text { Standar }\end{array}$ \\
\hline Tititk Nyala & SNI 2433-2011 & 290 & 232 & - & ${ }^{\circ} \mathrm{C}$ & $\begin{array}{l}\text { Memenuhi } \\
\text { Standar }\end{array}$ \\
\hline Berat Jenis & SNI 2441-2011 & 1,051 & 1 & - & $\mathrm{gr} / \mathrm{cc}$ & $\begin{array}{c}\text { Memenuhi } \\
\text { Standar }\end{array}$ \\
\hline $\begin{array}{l}\text { Berat Yang Hilang } \\
(\%)\end{array}$ & SNI 2441-1991 & 0,351 & - & 0,8 & $\%$ & $\begin{array}{l}\text { Memenuhi } \\
\text { Standar }\end{array}$ \\
\hline $\begin{array}{l}\text { Penetrasi Film Oven } \\
\text { Test }\end{array}$ & SNI $03-6835-2002$ & 69,70 & 54 & - & $\begin{array}{c}\% \\
\text { semula }\end{array}$ & $\begin{array}{l}\text { Memenuhi } \\
\text { Standar }\end{array}$ \\
\hline
\end{tabular}

\section{c. Pengujian Bulk untuk HRS Base}

Untuk menganalisis marshall konvensional maka sebelumnya harus diketahui terlebih dahulu nilai pengujian bulk (berat jenis) dari masing-masing agregat yang digunakan. Nilai hasil pengujian seperti pada tabel 3 .

Tabel 3. Hasil pengijian bulk.

\begin{tabular}{cccc}
\hline \multirow{2}{*}{$\begin{array}{c}\text { Gradasi } \\
\text { Agregat }\end{array}$} & \multicolumn{3}{c}{ Spesific Gravity } \\
\cline { 2 - 4 } & Bulk & Semu & Efektif \\
\cline { 2 - 4 } & $\mathrm{A}$ & $\mathrm{B}$ & $\mathrm{c}=(\mathrm{a}+\mathrm{b}) / 2$ \\
\hline Agregat Kasar & 2.64 & 2.77 & 2.70 \\
\hline Agregat Halus & 2.56 & 2.77 & 2.67 \\
\hline Filler (semen) & 3.09 & & \\
\hline
\end{tabular}

\section{d. Karasteristik Marshall Konvensional}

Hasil analisis nilai VIM (Void in Mix / rongga diantara partikel agregat yang tidak terisi oleh aspal) seperti pada gambar 2 .

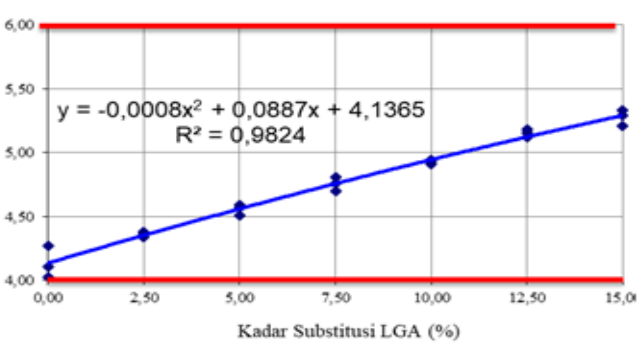

Gambar 2. Hubungan VIM dengan Kadar LGA

Penggunaan LGA 0\% - 15\% diperoleh nilai VIM antara $4,14-5,28$. Dari grafik tersebut diketahui bahwa semakin tinggi kadar LGA yang digunakan maka nilai VIM akan semakin kecil (berkurang) karena kadar LGA yang tinggi akan mengisi rongga-rongga dalam campuran sehingga rongga yang tidak terisi aspal (VIM) semakin berkurang.

Hasil analisis stabilitas terhadap kadar subtitusi kadar LGA seperti pada gambar 3 . 


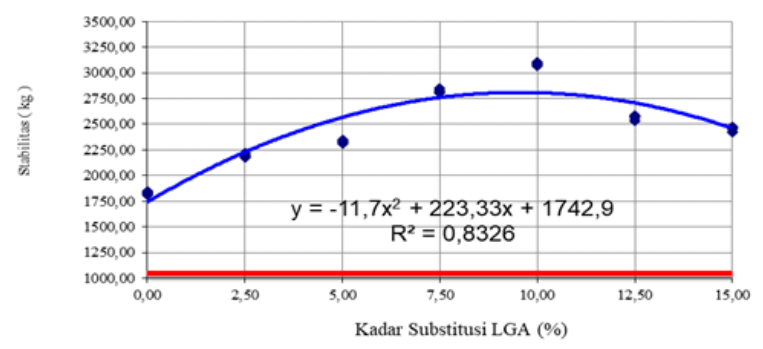

Gambar 3. Hubungan stabilitas dengan kadar LGA

Penggunaan LGA 0\% - 15\% diperoleh nilai Stabilitas antara 1828,01-2449,65. Stabilitas tertinggi terdapat pada kadar $10 \%$ yaitu 3083,60 . Dari grafik tersebut dapat diketahui bahwa setelah kadar $10 \%$ mengalami penurunan Stabilitas. Artinya nilai stabilitas dari penggunaan LGA dalam campuran akan maksimal pada takaran $10 \%$. Hal ini terjadi karena LGA juga mampu mengisi ruang dan mengikat agregat dengan aspal sehingga ikatan semakin tinggi

Hasil analisis terhadap VMA (Void in Mineral Aggregate) dapat dilihat pada gambar 4. Penggunaan LGA 0\% - 15\% diperoleh nilai VMA antara 18,1619,19. Berdasarkan gambar 4, maka dapat diperoleh bahwa semakin besar kadar asbuton maka akan semakin besar nilai VMA, dengan demikian penggunakan asbuton yang besar akan memberi rongga yang besar juga pada campuran aspal

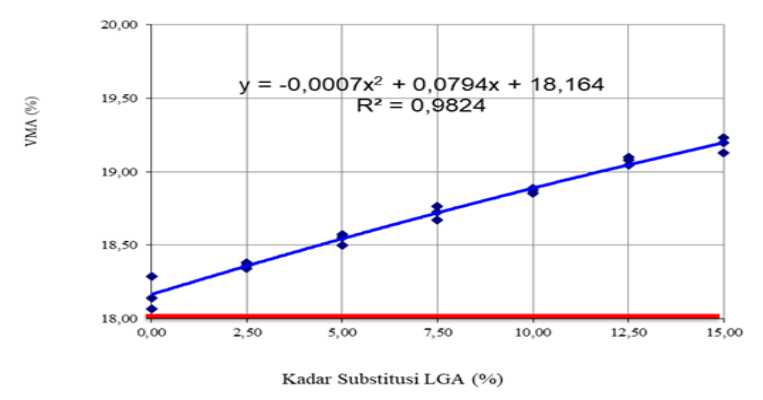

Gambar 4. Hubungan VMA dengan Kadar LGA

Hasil analisis MQ seperti pada gambar 5 di peroleh bahwa penggunaan aspal Buton 0\% - 15\% didapatkan nilai antara 494,39 - 737,88 kg/mm.

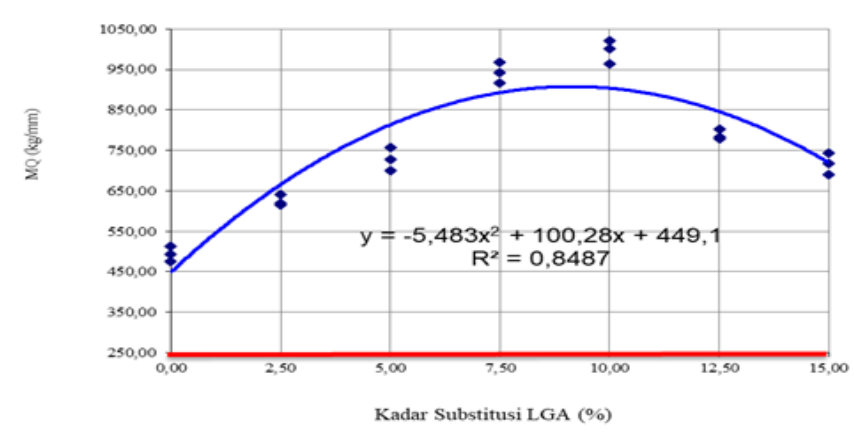

Gambar 5. Hubungan MQ dengan Kadar LGA

Berdasarkan Gambar 9 dapat diketahui bahwa pada kadar aspal buton $0 \%$ akan mengalami peningkatan sampai pada kadar aspal $10 \%$. Setelah itu akan kembali mengalmi penurunan nilai $\mathrm{MQ}$ seiring penambahan nilai atau jumlah kadar aspal buton.

Analisis terhadap VFB seperti pada gambar 6 .

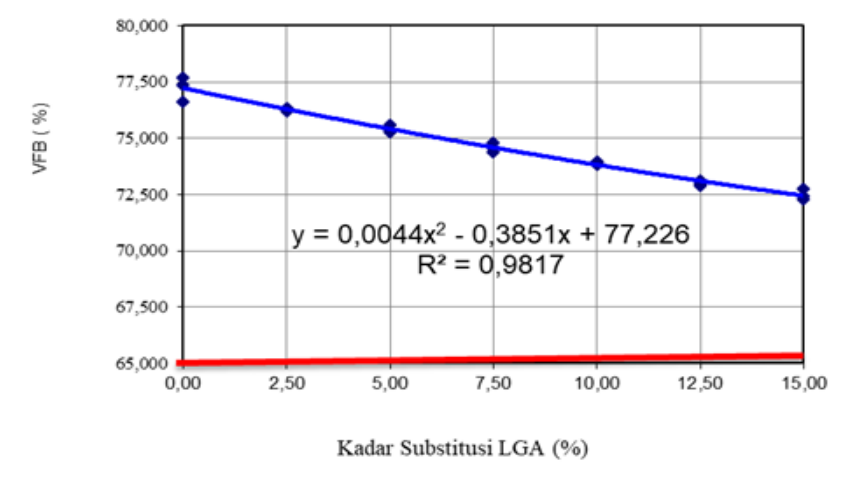

Gambar 6. Hubungan VFB dengan kadar LGA

Dari gambar 6 dapat diketahui bahwa penambahan kadar LGA 0\% - 15\% diperoleh nilai VFB antara 77,2372,49 . Penggunaan LGA akan berpengaruh pada nilai VFB campuran dimana semakin banyak mensubtitusi kedalam campuran maka nilai VFB akan mengalami penurunan. Artinya nilai VFB dan LGA tidaklah memberi peningkatan terhadap nilai VFB pada campuran HRS base

\section{e. Kadar Aspal Optimum}

Untuk campuran HRS Base di pilih yang memiliki nilai Stabilitas terbesar yaitu pada kadar LGA 10\% karena campuran HRS Base adalah lapisan yang berfungsi untuk memberi dukungan terhadap lapis permukaan, mengurangi regangan dan tegangan, menyebarkan dan meneruskan beban konstruksi jalan di bawahnya.

\section{f. Indeks Perendaman (IP)}

Salah satu pengujian untuk melihat indeks perendaman (ketahanan terhadap waktu perendaman) atau kekuatan suatu campuran, hasil dari pengujian ini adalah rasio stabilitas. Rasio tersebut membandingkan stabilitas dari benda uji Marshall setelah direndam dalam suhu $60^{\circ} \mathrm{C}$ dalam waterbath selama 24 jam terhadap stabilitas benda uji marshall dengan perendaman 30 menit yang biasa disebut indeks perendaman (IP) atau indeks kekuatan sisa (IKS).

Hasil pengujian Indeks perendaman dapat dilihat pada tabel 3

Dari hasil pengujian Marshall Immersion diperoleh indeks perendaman sebesar $95,21 \%$ dengan kadar LGA $10 \%$. Nilai indeks perendaman ini telah memenuhi Spesifikasi Umum Bina Marga 2018. Berdasarkan nilai tersebut dapat disimpulkan bahwa lapisan HRS Base dengan menggunakan aspal buton sebagai bahan subtitusi aspal minyak dapat tahan terhadap suhu dan lamanya terendaman dalam air. 
Tabel 3. Hasil pengujuan indeks perendaman

\begin{tabular}{cccc}
\hline \multirow{2}{*}{$\begin{array}{c}\text { Kadar Subtitusi } \\
\text { LGA (\%) }\end{array}$} & \multicolumn{2}{c}{ Stabilitas } & Indeks \\
\cline { 2 - 3 } & Konvensional & Immertion & Perendaman (\%) \\
\hline 10 & 1674,94 & 1604,31 & 95,78 \\
\hline 10 & 1695,12 & 1614,4 & 95,24 \\
\hline 10 & 1685,03 & 1594,22 & 94,61 \\
\hline Rata-Rata & 1685,03 & 1604,31 & 95,21 \\
\hline
\end{tabular}

\section{Pembahasan}

Berdasarkan Hasil pengujian karakteristik Agregat, untuk setiap pengujian karaktersitik agregat diperoleh bahwa agregat Sungai Jeneberang Kecamatan Bili bili Kabupaten Gowa memenuhi setiap pengujian karakteristik sesuai dengan ketentuan dari Spesifikasi Umum Bina Marga 2018.

Berdasarkan hasil rancangan komposisi campuran AC-BASE yang menggunakan agregat sungai Jeneberang dan ditambahkan dengan limbah kantong plastik telah memenuhi Spesifikasi Umum Bina Marga 2018, dimana kadar asbuton 0\%, 2,5\%, $5 \%, 7,5 \%, 10 \%, 12,5 \%, 15 \%$

Berdasarkan hasil pengujian Marshall Konvensional dan Marshall Immersion yang menggunakan bahan tambah limbah kantong plastik diperoleh:

Berdasarkan gambar 2 persamaan garis $y=-$ $0.0008 \times 2+0.0887 x+4.1365$ diperoleh nilai rongga dalam campuran yang tidak terisi oleh aspal/VIM (Void In Mix) akan berkurang sebesar rata-rata 0,19\% seiring dengan bertambahnya kadar LGA. Vim tidak mencapai batas minimum dimana nilai terendah pada hasil analisa yaitu $4,215 \mathrm{~mm}$. VIM juga tidak mencapai batas maksimum seperti yang telah di tentukan oleh karena nilai VIM tertinggi yang di peroleh dari hasil analisa yaittu 5,000

Persamaan garis $y=-11.7 x 2+223.33 x+1742,9$ pada gambar 3 menunjukkan bahwa Stabilitas mengalami peningkatan pada kadar aspal buton $2,5 \%$ sampai pada kadar aspal $10 \%$ dan akan kembali turun seiring dengan bertambahnya kadar LGA. Persamaan Regresi menunjukan bahwa stabilitas maksimum berada pada kadar aspal 10\% dengan nilai 3083,60.

Nilai VMA yang ditunjukkan pada gambar 4 dan persamaan garis $y=-0.0007 x 2+0.0794 x+18.16$ memperlihatkan kenaikan seiring dengan bertambahnya kadar LGA. Hal ini disebabkan karena Nilai Void in Meneral Agregate (VMA) sangat dipengaruhi oleh kadar aspal campuran, suhu pemadatan, jumlah tumbukan dan gradasi serta jenis agregat/batuan yang digunakan. Dari grafik dan hasil perhitugan menyatakan bahwa VMA tidak mencapai nilai minimum yang telah di tentukan sekalipun dengan kadar aspal buton $0 \%$.
Dari persamaan garis $y=-5.483 x 2+100.2 x+449.1$. pada gambar 5 menunjukkan bahwa MQ meningkat pada kadar LGA 0 hingga $10 \%$ dan akan kembali mengalami penurunan seiring penambahnan kadar aspal butonDari persamaan Regresi menunjukan bahwa MQ tidak mencapai nilai minnimum yang telahditentukan yaitu $250,75 \mathrm{~kg} / \mathrm{mm}$ dan nilai maksimum yang dicapai pada $\mathrm{MQ}$ ialah pada kadar asbuton $10 \%$

Persamaan garis $y=0.004 x 2-0.385 x+77.22$ pada gambar 6 menunjukkan bahwa dengan penamabahan kadar LGA sebagai pengganti aspal minyak akan memberikan peningkatan dan akan melewati batas minimum yang ditentukan pada nilai VFB akan tetapi grafik akan mengalami penurununan setiap penamabahan kadar aspal buton dalam campuran.Persamaan Regresi menunjukkan bahwa nilai VFB tidak mencapai

\section{KESIMPULAN}

1. Agregat dari Sungai Jeneberang Bili bili kabupaten Gowa dan aspal sebagai bahan campuran HRS Base

2. Pengaruh penambahan aspal buton dengan kadar $0 \% 2,5 \%, 5 \%, 7,5 \%, 10 \%, 12,5 \%$ dan 15 $\%$ dan kadar aspal 5\% memenuhi spesifikasi sebagai lapisan HRS Base

3. Nilai pengujian Marshall Immersion setelah melalui perendaman suhu $60^{\circ} \mathrm{C}$ dalam waterbath selama 24 jam memenuhi persyaratan spesifikasi Umum 2018 dimana diperoleh Indeks Perendaman atau Indeks Kekuatan Sisa (IKS) $95,21 \%>90 \%$ (Bina Marga) untuk HRS-base, yang artinya campuran tahan terhadap suhu, atau lamanya terendam dalam air.

\section{DAFTAR PUSTAKA}

[1] R. Krebs D. and R. Walker D.,1971, Highway Materials,. Michigan: McGraw-Hill, Universitas Michigan.

[2] Direktorat Jendral Bina Marga, 2014, Spesifikasi Umum Direktorat Jenderal Bina Marga Edisi 2010 Revisi 3 Divisi 6.

[3] R. Rachman, 2019, "Karakteristik Campuran HRS - BASE Menggunakan Bubuk Dolomit Sebagai Filler," presented at the KoNTekS-13, Banda Aceh, Sep. vol. 1, pp. 420-430,

[4] S. Sukirman, 2007, Beton Aspal Campuran Panas, Edisi Kedua. Jakarta: Yayasan Obor Indonesia, 2007.

[5] R. Rachman, 2012, "Evaluasi Kinerja Filler asbuton dalam Campuran Mortar Hot Rol Asphalt (HRA)," Jumal IIm. Adiwidia, vol. 4, no. 1, pp. 111, 2012.

[6] R. Rachman and Alpius, 2013, "Kinerja Campuran HRA Akibat Pengaruh Modifier pada Filler Asbuton Mikro," presented at the Prosiding 
Seminar Nasional Teknik Sipil UKIPaulus, Makassar, Indonesia, pp. 58-69.

[7] Yudi. I, Angga I, Elizabeth, and Alpius 2019, "Karakteristik Campuran AC-WC dan AC-BC Menggunakan Bahan Tambah Serat ljuk," Paulus Civ. Eng. J. Ojsukipaulusacid, vol. 1, no. 2, pp. 19.

[8] J. Putra Siada, R. Inrinto Alfin, M. Palinggi D, M., and R. Rachman, 2019, "Pengaruh Penggunaan Serat Rotan Terhadap Stabilitas Dan Durabilitas Untuk Bahan Tambah Campuran Lataston," Paulus Civ. Eng. J., vol. 1, no. 1, pp. 1-10.
[9] C. Kamba and R. Rachman, 2018, "Marshall Characteristics Test On Hot Rolled Sheet Base Combine Using Nickel Slag For Half Gap Graded," Int. J. Innov. Sci. Eng. Technol., vol. 5, no. 3, pp. 14-19.

[10] A. Kusuma and R. Rachman, 2018, "Study Characteristics of Nickel Slag For Gradient Gap on Mixtured Hot Rolled Sheet Base," Int. J. Innov. Sci. Eng. Technol., vol. 5, no. 3, pp. 8-13. 